\title{
The social adjustment of patients with schizophrenia: implications to the mental health policy in Brazil ${ }^{\star}$
}

\author{
Paulo R. Menezes**, Anthony H. Mann**
}

\begin{abstract}
MENEZES,P.R. \& MANN, A.H. The social adjustment of patients with schizophrenia: implications to the mental health policy in Brazil. Rev. Saúde Pública, 27: 340-9, 1993. A sample $(n=124)$ of schizophrenic patients from a defined catchment area of the city os S.Paulo, Brazil, who had been consecutively admitted to hospital, was assessed for psychopathological status and social adjustment levels. Sociodemographic, socio-economic and occupational characteristics were recorded: almost $30 \%$ of the subjects had no occupation and received no social benefit, more than two-thirds had a monthly per capita income of US\$ 100.00 or less. Sixty-five percent presented with Schneiderian first rank symptoms. Nearly half the sample showed poor or very poor social adjustment in the month prior to admission. The most affected areas of social functioning were participation in the household activities, work and social withdrawal. The current mental health policy of promoting extra-mural care as an alternative to the previous hospital-based model will then mean the investment in a network of new community-based services, that give effective treatment and support to patients and their families. The need of further research into the current picture of mental disorders in the country is stressed.
\end{abstract}

Keywords: Schizophrenia, epidemiology. Social adjustment. Health policy. Community mental health services.

\section{Introduction}

Schizophrenia is an important public health problem in developed countries, with prevalence rates of $5 / 1,000$ adult population ${ }^{24}$. Its costs to society are high, and comprise direct treatment costs (in-and-out-patient hospital care, residential care, community-based services), indirect costs due to lost of production, and intangible ones, such as human suffering due to the illness. Direct costs, which are most easily calculated, were estimated as $£ 1,670$ per year in the U.K., representing $1.6 \%$ of the total health and personal social expenditure in that country in $1987^{14}$. In Australia, the costpernew case was calculated as being U.S.\$131,333, and the total direct costs reached as much as half the amount spent on myocardial infarction ${ }^{4}$. There is a lack of information about the burden schizophrenia represents to society in developing countries, but extrapolations from incidence rates and demographic trends suggest that the number of cases under care in these countries will grow by $87 \%$ from 1975 to the year $2000^{28}$

* Supported by "Conselho Nacional de Desenvolvimento Científico e Tecnológico-CNPq" through Dr. P.R.Menezes scholarship. Processo n²03023/90.0

** Institute of Psychiatry Section of Epidemiology and General Practice - London - United Kingdom

Reprints: P.R.Menezes - De Crespigny Park London SE5 8AF United Kingdom

Edição subvencionada pela FAPESP. Processo Medicina 93/0208-5
Despite the more optimistic views about the outcome of schizophrenia in recent years, it continues to be a disabling condition for at least one third of those affected by $\mathrm{it}^{21}$. Attention has been given to the evaluation of social disability as a specific consequence of the illness, only partially associated with severity of psychopathological status ${ }^{12,16}$. Such investigations have showed that there is at least some degree of social disability in two-thirds of the individuals suffering from schizophrenia. Adequate knowledge of the types and intensity of this disability is necessary for the planning of services and programmes targeted at providing extramural care for schizophrenic patients ${ }^{37}$.

\section{Schizophrenia in Brazil}

Although to date there has been no epidemiological study aimed specifically at evaluating the prevalence of schizophrenia in Brazil, the rate seems to be similar to those figures found for other countries, being around 5/1,000 adult population ${ }^{1,7,32}$. The diagnosis of schizophrenia accounts for about one-third of all psychiatric admissions ${ }^{36}$.

Regarding social disability, Shirakawa ${ }^{38}$ investigated a sample of 44 schizophrenic patients who had been attending a private psychiatric office for many years, and assessed their social adjustment using a standardized instrument. The sample had high levels of social disabilities. Less than $15 \%$ of them were receiving salaries that could allow them to live independently. Relatives expected higher levels of social functioning 
from males than from females. However, this sample probably consists of a group that is socially and culturally different from patients attending the psychiatric hospitals of the public health system in Brazil.

\section{Mental health policy in Brazil}

During the 1960's and 1970's the mental health policy in Brazil was characterized by the hospital-based model, with an increasing number of psychiatric beds throughout this period ${ }^{2,31}$. In recent years there has been a shift in the mental health policy towards a communityorientated care for mentally ill people ${ }^{222}$. The number of psychiatric beds fell from 105,765 in 1984 to 85,037 in 1991 , a $20 \%$ reduction 2 .

This new policy will have important implications for the patients, their families and the communities they live in however, the current lack of information on the characteristics of those patients that are being affected by change in policy, in particular their social disability levels, makes difficult adequate planning for services and programs, and for the training of professionals properly qualified to deal with them and their families.

In the present study, a sample of schizophrenic patients who lived in a defined catchment area of the city of S. Paulo, and who were consecutive admissions to the psychiatric hospitals of that area, was assessed for inclusion in a prospective study on patterns of contact with health care services and outcome of schizophrenia. This present paper aims to describe their characteristics, with special reference to their social adjustment, and to discuss the findings in the light of the current mental health policy in Brazil.

\section{Method}

\section{The catchment area}

The catchment area chosen is a regional health district located in the Northern region of the city of S. Paulo, identified as the "Sistema Descentralizado e Unificado de Saúde - Região 6 (SUDS-R6)". The psychiatric health care system in this area is organized in accordance with the principles of regionalization, with hierarchic levels of complexity and integration between services, characteristics that facilitate the execution of epidemiological studies ${ }^{36}$. The area is served by apsychiatric ward in a general hospital, with 20 beds, and 3 psychiatric hospitals with a total of about 1,500 beds. There is no shortage of psychiatric beds for individuals living in the area. All psychiatric admissions are centrally recorded and managed by a psychiatric register, on a daily basis. The register records the name, address, sex, age, the psychiatric diagnosis at admission, the unit that referred the patient for admission and the hospital which admitted the patient.
The aim of case-finding was to select individuals presenting with specific symptoms and behavioral abnormalities indicative of schizophrenia, definite or probable, regardless of pre-existing diagnostic labels. The psychiatric register was scrutinized to identify all possible cases of schizophrenia that were living in the study catchment area, were aged between 15 and 44, who had had an admission to one of the psychiatric hospitals of the area during the period between 1 June and 22 August 1991, with a diagnosis of either 'schizophrenia', "paranoid psychosis' or 'other functional psychoses', recorded according to the 9 th version of the International Classification of Diseases ${ }^{46}$.

Medical records were then checked, and exclusion and inclusion criteria were applied. Exclusion criteria were: alcohol or drug dependence in the last year, severe mental retardation, organic psychoses, epilepsy, hearing or speech difficulties that could impede the administration of interviews, and planning to leave S. Paulo after discharge from the psychiatric hospital. Inclusion criteria were at least one of the following symptoms: mood-incongruent delusions, definitely inappropriate or unusual behaviour, hallucinations, disorders of thinking or language, other than acceleration or retardation; or at least two of the following: psychomotor disturbance other than acceleration or retardation, social withdrawal, overwhelming fear, and self-neglect.

If patients were still eligible for entry into the study, they were then interviewed for the assessment of psychiatric symptoms, after giving their consent to participate in the study. The interview normally took place during the first two weeks of admission. That procedure was followed by an interview with a key informant, generally a relative of the patient, when the scale for evaluating social adjustment was applied.

\section{Assessments}

Assessments were made in a similar way for all patients. They included data on sociodemographic variables (sex, age, ethnic group, marital status, religion, educational level, occupational status, profession, living arrangements, and monthly economic income), psychiatric history and diagnosis, psychopathologic status and social adjustment in the month prior to admission.

For the assessment of psychiatric symptoms a standardized psychiatric interview was utilized, the 9th version of the Present State Examination (PSE) ${ }^{44}$. A classification based on the cross-sectional symptomatology was given by the CATEGO, a computer program developed for use with the PSE ${ }^{45}$. The investigating psychiatrist was trained in the use of the instrument by the MRC Social Psychiatric Unit, in London, and used a Brazilian translation of the instrument into Portuguese $^{8}$. By adding a 30-item questionnaire covering longitudinal aspects of the disorder, diagnoses 
according to the "Diagnostic and Statistic Manual of Mental Disorders"3 (DSM-III-R) were also obtained.

For the assessment of social disability the WHO Psychiatric Disability Assessment Schedule (DAS) ${ }^{47}$ was used. This scale has been specially developed for the purpose of assessing social functioning in a variety of different settings and cultures, is available in many languages, and has been used in several countries in a series of multicentre studies coordinated by the WHO. In the present study a translation into Portuguese ${ }^{10}$ was applied by one of 2 interviewers, a psychiatrist and a psychologist, to a key-informant of the patients, generally a relative. This interview was carried out independently of the psychiatric examination. Sections 1,2 and 5 were used (see Appendix). Section 1 deals with overall behavior, and gives the degree of disability for activities of daily living and relates to the immediate physical environment. Section 2 is an inventory related to the perfomance of social roles, such as work, parental duties, sexual relationships. Section 5 is a global evaluation of social functioning based on all the information obtained for sections 1 and 2. Scores for each item in sections 1 and 2 range from 0 , 'no dysfunction', to 5 , 'maximum dysfunction'. Scores for section 5 range from 0 , 'excellent or very good adjustment', to 5 , 'severe maladjustment'. The baseline against which the patients behaviour is measured is the presumed 'average' or 'normal' functioning of a person of the same sex and of comparable age and socio-economic environment. An inter-rater reliability assessment was carried out by means of 20 simultaneous interviews carried out by the 2 interviewers.

\section{Analysis}

Data handling and analysis were carried out using the computer program for epidemiological studies Epi Info $5^{17}$. The distribution of socio-demographic and socio-economic variables, psychopathological status, and social disability levels were examined. Chi-square tests were carried out to examine differences between groups for categorical variables, t-tests for differences in continuous variables, and correlation coefficients were used to examine the relationship between continuous variables. Inter-rater reliability was assessed through the calculation of intra-class correlation coefficients ${ }^{5}$.

\section{Results}

Of 217 patients screened during the period between 1 June and 22 August 1991, 124 were included in the study ( 69 men and 55 women). The remaining 93 subjects were excluded, the most common reasons being non-catchment area $(n=20)$ and alcoholism $(\mathrm{n}=19)$.

The mean age was 32.6 years, ranging from 19 to
44 years $(S D=6.9)$. The sample was predominantly white, single, Catholic, born outside S. Paulo, and with more than 4 years of education (Table 1). The monthly per capita income ranged from US $\$ 16.50$ to US\$ 750.00 , with $71.7 \%$ of the individuals having a montly per capita income of US\$ 100.00 or less (Figure 1).

The proportion of subjects with any occupation at the time of the admission was low (26.6\%), and only 24 were working regularly, either as employees or self-employed. Twenty-seven subjects were on social benefits, males predominating in this group ( 20 vs. 7 females, $x^{2}=4.75,1$ d.f., $p=0.03$ ).

\section{Psychiatric characteristics}

Ninety-four subjects $(75.8 \%$ ) had had one or more admissions to psychiatric hospitals in the past, and $27.6 \%(n=34)$ had had 10 or more psychiatric admissions; 30 subjects were first admissions. The average

Table 1. Socio-demographic characteristics of the study sample, by $\operatorname{sex}(n=124)$.

\begin{tabular}{|c|c|c|c|}
\hline Characteristc & Males(\%) & Females(\%) & Total $(\%)$ \\
\hline \multicolumn{4}{|l|}{ Age Group } \\
\hline 15 to 24 & $13(18.8)$ & $7(12.5)$ & $20(16.1)$ \\
\hline 25 to 34 & $26(37.7)$ & $25(45.5)$ & $51(41.1)$ \\
\hline 35 to 44 & $30(53.5)$ & $23(41.8)$ & $53(42.7)$ \\
\hline \multicolumn{4}{|l|}{ Ethnic Group } \\
\hline white & $57(82.6)$ & $33(60.0)$ & $90(72.6)$ \\
\hline black & $0(0.0)$ & $4(7.3)$ & $4(3.2)$ \\
\hline oriental & $3(4.3)$ & $2(3.6)$ & $5(4.0)$ \\
\hline mixed & $9(13.0)$ & $16(29.1)$ & $25(20.2)$ \\
\hline \multicolumn{4}{|l|}{ Place of Bith } \\
\hline SP capital & $27(39.1)$ & $24(43.6)$ & $51(41.1)$ \\
\hline SP state & $11(15.9)$ & $8(14.5)$ & $19(15.3)$ \\
\hline South-East & $14(20.3)$ & $5(9.1)$ & $19(15.3)$ \\
\hline North-East & $16(23.2)$ & $15(27.3)$ & $31(25.0)$ \\
\hline other & $1(1.4)$ & $3(5.4)$ & $4(3.2)$ \\
\hline \multicolumn{4}{|l|}{ Religion } \\
\hline catholic & $47(68.1)$ & $29(53.7)$ & $76(61.3)$ \\
\hline evangelic & $14(20.3)$ & $13(24.1)$ & $27(24.1)$ \\
\hline other & $5(7.2)$ & $9(16.7)$ & $14(11.3)$ \\
\hline none & $4(5.8)$ & $3(5.6)$ & $7(5.6)$ \\
\hline \multicolumn{4}{|l|}{ Marital Status } \\
\hline single & $52(75.4)$ & $29(52.7)$ & $81(65.3)$ \\
\hline married & $9(13.0)$ & $12(21.8)$ & $21(16.9)$ \\
\hline separated & $7(10.1)$ & $12(21.8)$ & $19(15.4)$ \\
\hline widowed & $1(1.4)$ & $2(3.6)$ & $3(2.4)$ \\
\hline \multicolumn{4}{|l|}{ Education } \\
\hline illeterate & $4(5.8)$ & $3(5.5)$ & $7(5.6)$ \\
\hline less than 4 years & $9(13.0)$ & $19(34.6)$ & $28(22.6)$ \\
\hline 4 to 8 years & $38(55.0)$ & $18(32.7)$ & $56(45.2)$ \\
\hline 9 years and plus & $18(26.0)$ & $15(27.3)$ & $33(26.6)$ \\
\hline
\end{tabular}




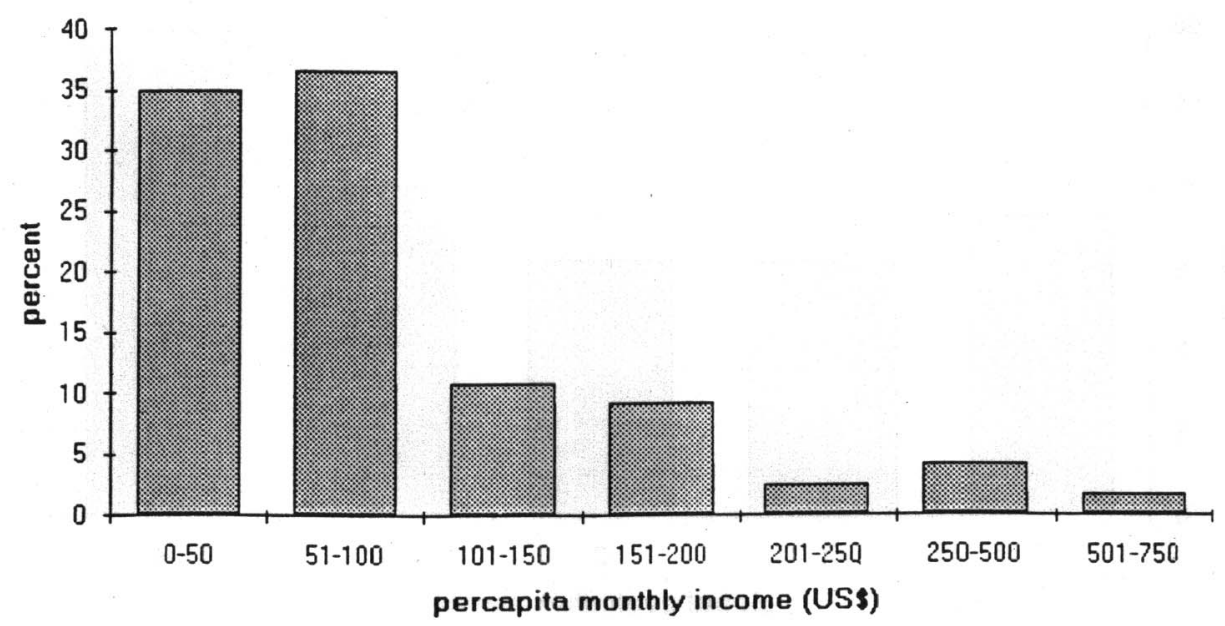

Figure 1. Distribution of per capita montly income.

length of illness was 8.3 years $(S D=6.9)$, randing from 0 to 27 years. Men had more years of illness than women (9.5 vs. 6.7, $\mathrm{p}=0.021$ ).

The distribution of diagnoses according to the DSM-III-R and the frequency of CATEGO classes are given in Table 2 . It can be seen that $71.8 \%$ of the subjects were classified as 'schizophrenia' by both criteria, if one considers as such classes $S$ and $P$ for the CATEGO and schizophrenia, schizophreniform and schizoaffective psychoses for the DSM-III-R are include in this broad category. Only 6 subjects (4.8\%) were not classified as schizophrenia by either CATEGOorDSM-III-R.

\section{Social adjustment}

The WHO/DAS was applied to 115 patients; it was not possible to obtain information in 3 cases, due to lack of contact with relatives prior to admission, and 6 cases had been at home for less than 15 days between the index admission and the previous one. The inter-rater reliability of the WHO/DAS was very good, with intra- class correlation coefficients ranging from 0.88 to 1.00 . Further details on the reability study may be found elsewhere ${ }^{33}$.

The distribution of section 5 (Global Evaluation) scores in shown in Figure 2;81.6\% of the subjects were assessed as having at least some impairment in social functioning (score 1 or above), and 50\% were assessed as having poor or very poor social adjustment (scores 3 and 4 , respectively) in the month prior to admission. Global scores were positively correlated with length of illness $(\mathrm{r}=0.26,0.08<\mathrm{r}<0.42, \mathrm{f}=7.92, \mathrm{p}<0.01)$, when the later was grouped as $0-1,2-5,6-10$ and 11 or more years of illness and coded as an ordered categorical variable.

The analysis of the frequency distribution of scores for each item of the schedule allows the identification of those areas of social adjustment that were the most affected by the illness (Table 3). Participation in household activities was the item with the highest proportion of subjects scoring 1 or more (73.9\%), followed closely by social withdrawal $(73.1 \%)$. If items for work performance (2.7) and interest in getting a job (2.8) are consid-

Table 2. Distribution of diagnoses according to DSM-1II-R and PSE-CATEGO

\begin{tabular}{|c|c|c|c|c|c|c|}
\hline \multicolumn{7}{|c|}{ DSM-III-R } \\
\hline PSE & Schizophrenia & Schizophreniform & Schizoaffective & Affective & $\begin{array}{c}\text { Other } \\
\text { Psychoses }\end{array}$ & Total \\
\hline S & 54 & 13 & 6 & 7 & 2 & 82 \\
\hline$P$ & 16 & & & & 1 & 17 \\
\hline 0 & 12 & 2 & 1 & 1 & & 16 \\
\hline M & 2 & & & 2 & & 4 \\
\hline$D$ & 1 & & & 1 & & 2 \\
\hline$R$ & & & & 2 & & 2 \\
\hline$x$ & 1 & & & & & 1 \\
\hline Total & 86 & 15 & 7 & 13 & 3 & 124 \\
\hline
\end{tabular}




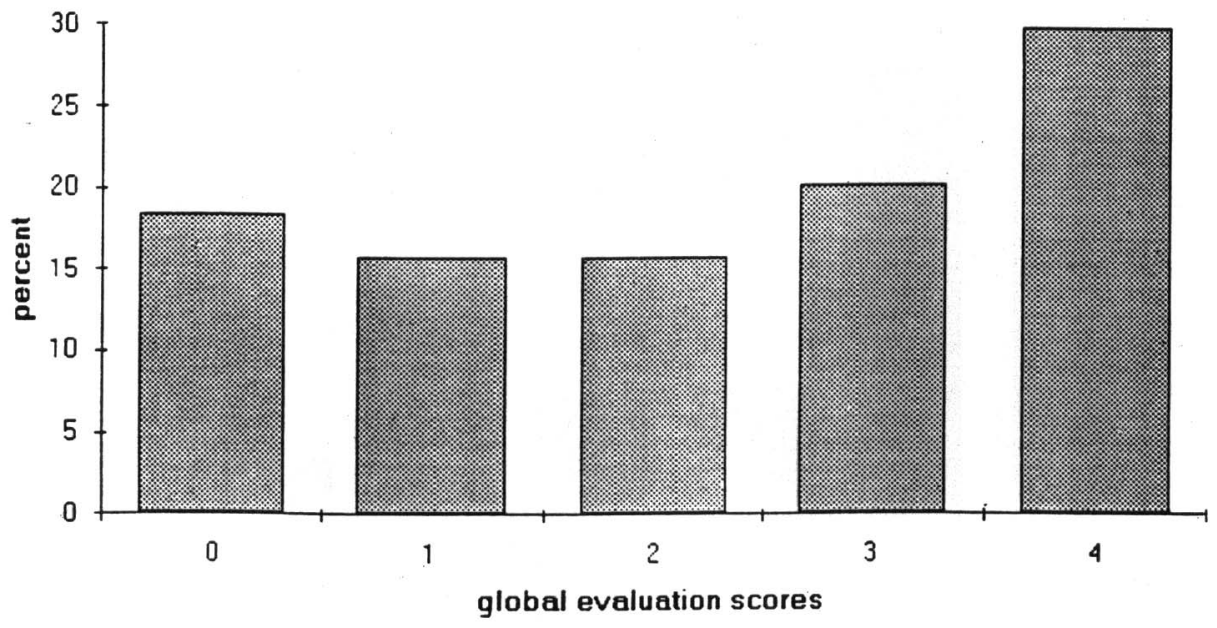

Figure 2. Distribution of WHO DAS global evaluation scores

Table 3. Distribution of scores per WHO/DAS item, in percents $(n=115)$

\begin{tabular}{|c|c|c|c|c|c|c|c|}
\hline \multirow[t]{2}{*}{ Item } & \multicolumn{7}{|c|}{ Score } \\
\hline & 0 & 1 & 2 & 3 & 4 & 5 & 9 \\
\hline 1.1 self-care & 44.3 & 12.2 & 14.8 & 17.4 & 8.7 & 2.6 & \\
\hline 1.2 underactivity & 42.6 & 10.4 & 7.8 & 11.3 & 18.3 & 8.7 & 0.9 \\
\hline 1.3 slowness & 62.6 & 7.8 & 7.8 & 6.1 & 10.4 & 0.9 & 4.4 \\
\hline 1.4 social withdrawal & 25.2 & 7.8 & 14.8 & 14.8 & 20.0 & 15.7 & 1.7 \\
\hline 2.1 participation & 22.6 & 12.2 & 13.9 & 7.8 & 15.7 & 24.3 & 3.4 \\
\hline 2.2 marital / affective & 6.1 & 2.6 & 1.7 & 3.5 & 0.9 & 2.6 & 82.6 \\
\hline 2.3 marital / sexual & 3.5 & 0.0 & 0.9 & 2.6 & 3.5 & 2.6 & 86.9 \\
\hline 2.4 parental & 13.0 & 6.1 & 4.3 & 2.6 & 3.5 & 6.1 & 64.3 \\
\hline 2.5 sexual & 9.6 & 4.3 & 4.3 & 14.8 & 29.6 & 4.3 & 33.0 \\
\hline 2.6 social contacts & 58.3 & 8.7 & 6.1 & 4.3 & 4.3 & 14.3 & 13.9 \\
\hline 2.7 work performance & 8.7 & 5.2 & 0.9 & 6.1 & 2.6 & 2.6 & 73.9 \\
\hline 2.8 interest in job & 4.3 & 6.1 & 2.6 & 6.1 & 27.0 & 13.0 & 40.8 \\
\hline 2.9 information & 30.4 & 9.6 & 7.0 & $\$ 1.3$ & 9.6 & 27.8 & 4.4 \\
\hline 2. 10 emergencies & 39.1 & 6.1 & 2.6 & 4.3 & 10.4 & 13.9 & 23.5 \\
\hline
\end{tabular}

ered to represent dysfunction in the same area and are added together, $72.2 \%$ of the patients had been given a score of at least 1 . The same was done for items on sexual role for married and unmarried subjects (items 2.3 and 2.5 , respectively); $66.9 \%$ had a score of 1 or above. On the other hand, social contacts $(27.8 \%)$, slowness $(33.1 \%)$, and behavior in emergencies $(37.4 \%)$ were the items where fewer subjects were reported to have any disability.

In terms of severity of disability, when considering work performance and interest in getting a job taken together, this was the area with the highest proportion of subjects showing marked degrees of disability, with $45.2 \%$ of them scoring 4 or 5 . Participation in the household followed, with $40 \%$ of subjects scoring 4 or
5. Sexual relationship (married and unmarried together), interest in information and social withdrawal also had high proportions of scores 4 or $5(39.0 \%, 37.4 \% \mathrm{nad}$ $35.7 \%$, respectively).

\section{Discussion}

This is the first study carried out in Brazil in which a sample of schizophrenic patients from a defined catchment area, who had been recently admitted to psychiatric hospitals of the public health system, were assessed systematically with standardized instruments for mental state and social adjustment. Almost $30 \%$ of the subjects had no occupation or social benefit. More 
than two-thirds had a monthly per capita income of US\$ 100.00 or less. Sixty-five percent presented with Schneiderian first rank symptoms. Nearly half the sample showed poor or very poor social adjustment in the month prior to admission.

\section{Methodological considerations}

The sample was limited to patients aged $15-44$ years, but those over this age range represent only $20 \%$ of the admissions for non-affective functional psychoses in the study catchment area. The exclusion criteria limited the sample to patients without concurrent drug or alcohol dependence. This subgroup, which represents something around $15 \%$ of all patients with diagnosis of non-affective functional psychoses who live in the area and are admitted psychiatric hospitals, may have worse levels of social adjustment and deserves further investigation. The sample is also restricted to those patients who use the public health system, but only a very small proportion of the population can afford pychiatric in-patient treatment on a private ba$\mathrm{sis}^{22}$. Apart from these limitations, the distribution of clinical diagnoses, age and sex in the sample are similar to those observed during a 1-year period $(01.07 .90$ to 30.06.91) for both the catchment area and a neighbouring area that uses the same psychiatric hospitals as their in-patient resources, according to data from the register. Therefore, the sample is very likely to be representative of all patients with schizophrenic psychoses in the age range 18-44 years who have a fixed address and are admitted to psychiatric hospitals of the public health system in S. Paulo without the associated conditions listed in the exclusion criteria.

The assessment of psychiatric symptoms and subsequent diagnostic classification present a considerable degree of subjectivity, but reliability between different investigators has been markedly improved by the use of standardized instruments ${ }^{42}$. This is the case with the PSE, which has showed good reliability coefficients, and has been widely used in psychiatric research all over the world ${ }^{14}$.

Similar difficulties exist for the evaluation of social adjustment levels ${ }^{25}$. The schedule chosen for this study, the WHO/DAS, was developed specifically for the assessment of patients behaviour and social functioning in the particular social and cultural settings. Acceptable levels of reliability have benn achieved, and its items have proved to be valid for the purpose of measuring social disability ${ }^{16}$.

\section{Levels of social disability in the sample}

The proportion of patients with any social disability was very high. More than $80 \%$ of the sample showed some degree of social disability (global evaluation scores 1 to 4), and almost $30 \%$ were severely disabled in their global social functioning (score 4). Ciompi ${ }^{11}$, in a long-term follow-up study of 289 schizophrenic patients in Switzerland, found that the overall social adaptation appeared to be good or fair in only one-third old the sample by the end of the study. In a study of 70 first episode schizophrenics in Germany, Schubart et al. ${ }^{37}$ reported that two-thirds had DAS global scores of 3 (poor adjustment) or more at 2-year follow-up. In the study by Shirakawa ${ }^{38}$, in Brazil, $43.2 \%$ of the sample had low scores (poor) and another $47.7 \%$ had intermediate scores in the assessment of global social functioning. The positive correlation between global evaluation scores and length of illness confirm the general view that the longer the condition lasts, the worse is the outcome ${ }^{13}$.

Regarding specific areas of social functioning, it becomes clear that some areas are more affected than others, mainly participation in the household activities, social withdrawal, work and sexual relationships. De Jong et $\mathrm{al}^{16}$, in a two-year follow-up study of 82 recent onset schizophrenics in Holland, showed that there is a hierarchical disruption in social roles and behaviours, the most affected areas being work, heterosexual and social contacts, while self-care remains relatively preserved. Westermeyer and Harrow ${ }^{41}$, in a review on the course and outcome of schizophrenia, pointed out that impaired social and family relationships are frequently observed in these patients, and that work impairment is a central feature of the illness.

\section{Implicationsfor a community-basedmentalhealthpolicy}

The mental health policy in Brazil has now been orientated towards dehospitalization and communitybased care, following a trend observed in some developed countries for more than 30 years now $w^{6,40}$. Positive results for this policy in other countries have been published, both in terms of patient outcome ${ }^{20,39}$ and of economic $\operatorname{costs}^{19,43}$. However, the negative consequences of such a policy of dehospitalization not followed by a corresponding increase in the investment in community care has also been described ${ }^{26,30,35}$. Many investigators have stressed the need of well planned extra-mural facilites and programs, if such a policy is to succeed ${ }^{9,26,28}$.

Community-based services will have to provide comprehensive treatment schemes, including pharmacological, psychological and social management ${ }^{23}$. The usefulness of neuroleptic drugs in the treatment of schizophrenia is well documented ${ }^{15}$, but under normal treatment conditions results are as not as good as those observed in clinical trials ${ }^{27}$. Almost $50 \%$ of the patients have a relapse within one year of their last episode, and one of the main reasons is the lack of compliance with neuroleptic medication. Therefore, the active monitoring of patients' contacts with extra-hospital services in order to ensure compliance with medication is essential. 
Rehabilitation programs are another necessary dimension of the community-care strategy, and their need in Brazil can be seem by the high levels of disability in social functioning found in this study. They should be provided by multidisciplinary teams, for patients' needs are of various orders ${ }^{23}$, occupational skill training, actual help in seeking jobs, and adequate housing provision being among the main issues for the proper maintenance of schizophrenic patients in the community ${ }^{34}$.

Thirdly, patients' relatives cannot be forgotten, whether they are those real carers for the patients or not $^{29}$. The burden relatives face when they have a schizophrenic patient at home has been well documented, and involves a damaging effect on social and leisure activities, financial and employment difficulties, and mental and physical health problems. Moreover, they are generally neglected by mental health professionals involved in the patients' treatment, even in the provision of information about the nature of the illness and how best to deal with these patients in their family surroundings. Adequate support for relatives is then absolutely necessary, and can even be cost-effective, in the measure in which it reduces future morbidity in both patients and the relatives who care for them.

The creation of population-based case registers make a valuable resource for the provision of detailed, longitudinal, inter-agency statistics that allow the study of the incidence, prevalence, course and outcome of schizophrenia, as well as service utilization patterns and evaluation of specific forms of care ${ }^{18}$. They are also very helpful in identifying those patients who lose contact with their treatment centres.

The implementation of such comprehensive care in Brazil will require careful assessment of the needs of each individual patient and good liason between the services and facilities patients need. Even if such services are provided, there is still the need of careful and continuous monitoring of their adequacy and effectiveness in meeting their original targets ${ }^{20}$.

A community-based network for the care of schizophrenic patients will require considerable re-allocation of resources, from spending on hospital care to the extra-mural system, extra money beig at the outset necessary for the implementation of the new network. However, in the area where this study was carried out there were only two out-patient clinics for a population of about one milion inhabitants, and no new community mental health facility had been created for the last 5 years. There has been a constant loss of professional staff, due to the low salaries and work overload. With the exception of a few isolated cases, there is no reason to imagine that the situation is too different in other regions of the country.

The Mental Health Section of the Brazilian Health Ministry has recently stressed its commitment to a community-based care strategy, established the change in financing from hospital beds to community-based services as a priority action, and proposed a joint action with the State Health Secretariats in order to implement such a policy ${ }^{2}$. Whether in practice health administrators will accept the $20 \%$ reduction in psychiatric beds only as a helpful economy measure resulting from the new policy in a moment of deep economic crisis or whether they will recognize the need to invest in community services and reallocate resouces remains to be seen.

\section{Conclusions}

Despite all the advances in its treatment, the prognosis of schizophrenia remains a guarded one for many patients, and disabilities in social functioning are among the main consequences of the illness. A communitybased strategy of care can be a successful alternative to the old hospital-based model. However, such a policy will only succeed and be accepted by society if a comprehensive extra-mural network of care is developed on the basis of the actual needs of patients and their families. Without it those who are supposed to benefit most from community-based care, the patients and their families, will be greatly penalised.

MENEZES, P.R. \& MANN, A.H. O ajustamento social de pacientes com esquizofrenia: implicações para a política de saúde mental no Brasil. Rev. Saúde Pública, 27:340-9 , 1993. A esquizofrenia é um importante problema de saúde pública em países desenvolvidos, afetando em média $0,5 / 1000$ pessoas adultas e causando altos custos econômicos para a sociedade. Em países menos desenvolvidos não há muitas informações disponíveis, mas projeções baseadas nas taxas de incidência e tendências demográfica sugerem que o número de casos nesses países deve aumentar em $87 \%$ de 1975 ao ano 2000 . No Brasil o diagnóstico de esquizofrenia representa cerca de um terço de todas as intemações psiquiátricas, e até o presente existe uma falta de informações sobre as condições reais desses pacientes. Com esse objetivo, uma amostra $(n=124)$ de pacientes esquizofrênicos residentes em uma região geográfica de captação definida na cidade de São Paulo, Brasil, e que haviam sido internados consecutivamente em hospitais psiquiátricos dessa região, foi avaliada quanto à psicopatologia e níveis de ajustamento social. Características sociodemográficas, socioeconômicas e ocupacionais também foram registradas. Os resultados indicaram uma população de pacientes com altos níveis de comprometimento psiquiátrico e de ajustamento social. Sessenta e cinco por cento apresentavam sintomas nucleares de esquizofrenia. Quase metade da amos tra apresentou ajustamento social pobre ou muito pobre no mês anterior à internação psiquiátrica. As áreas de funcionamento social mais afetadas foram participação nas atividades domésticas, trabalho e isolamento social.Quase $30 \%$ da amostra não tinha nenhuma ocupação e não recebia nenhum tipo de benefício social, e mais de dois terços tinham renda per capta mensal de US $\$ 100.00$ ou menos. A política de saúde mental atual de promover cuidados extrahospitalares como alternativa ao modelo hopitalocêntrico anterior implicará o investimento para a criação de uma rede de novos serviços de saúde mental, baseados na comunidade, que 
possam dar tratamento e apoio efetivos aos pacientes e suas famílias. É reforçada a necessidade de nov as investigações sobre o quadro atual de problemas psiquiátricos no país.

Descritores: Esquizofrenia, epidemiologia. Ajustamento social. Política de saúde. Serviços comunitários de saúde mental.

\section{References}

1. ALMEIDA, N. Fo;MARI, J.J.;COUTINHO, E.S.F.; FRANÇA J.F.; FERNANDES, J.G.; ANDREOLI, S.B.; BUSNELLO E. Estudomulticêntrico de morbidade psiquiátrica em áreas urbanas brasileiras (Brasîlia, São Paulo, Porto Alegre). Rev ABP-APAL, 14: 93-104, 1992.

2. ALVES,D.S.Y.: SEIDL,E.M.F.;SCHECHTMAN, A.: SILVA R.C. Elementos para uma análise da assistência em saúde mental no Brasil. J. Bras. Psiquiatr., 41:423-6, 1992.

3. AMERICAN PSYCHIATRIC ASSOCIATION. Diagnostic and statistical mantal of nental disorders. $3 \mathrm{rd}$. Ed. Revised (DSM-III-R). Washington. 1987.

4. ANDREWS, G.; HALL, W.; GOLDSTEIN,G.; LAPSLEY. H: BARTELS, R: SILOVE, D. The economic costs of schizophrenia. Arch. Gen. Psychiatry, 42: 537-43, 1985.

5. BARTKO, J.J. Measurement and reliability:statistical thinking considerations. Schizophr. Bull, 17:483-9, 1991.

6. BURNS, T.P.Community care and rehabilitation. Cum. Opin Psychiatry, 2:273-7, 1989.

7. BUSNELLO, E.; PEREIRA, M.O.; KNAPP, W.P.: SALGADO, C.A.; TABORDA, J.G.; KNIJNIK, L.; CEITLIN, L.H.; HOFMEISTER,M.R.; OLIVEIRA, N.B.;PICON, P.; BELTRÃO. S.M.; GIGANTE, L. Morbidade psiquiátrica na população urbana de Porto Alegre. J. Bras. Psiquiatr. 41:507-12, 1992.

8. CAETANO, R \& GENTIL, V. Glossário das definições dos sintomas incluídos na $9^{a}$ ediçāo do PSE. São Paulo, 1983. [mimeografado].

9. CAMPBELL,P.G.; TAYLOR. J.; PANTELIS, C.; HARVEY, C. Studies of schizophrenia in a large mental hospital proposed for closure, and in two halves of an inner London borough served by the hospital. In: Weller, M. International perspectives in schizophrenia: biological, epidemiological and social findings. London, John Libbey, 1990. p. 185 202.

10. CHAVES, A.C.;SARIN, L.M.: MARI, J.J. Escala de avaliação de incapacitação psiquiátrica (DAS). São Paulo. Escola Paulista de Medicina, 1990. [mimeografado].

11. CIOMPI, L. The natural history of schizophrenia in the long term. Br.J. Psychiatry, 136: 413-20, 1980.

12. COOPER, J.E. \& BOSTOCK. J. Relationship between schizophrenia, social disability, symptoms and diagnosis. In: Henderson \& Burrows. Handbook of social psy. chiatry. London, Elsevier Science Publishers, 1988. p. 317-30.

13. CUTTING, J. Outcome of schizophrenia: overview. In: Kerr. A. \& Snaith, P. Contemporary issues in schizophrenia. London, Gaskell, 1986.p. 433-40.

14. DAVIES, L.M. \& DRUMMOND. M.F. The economic burden of schizophrenia. Psychiatr. Bull., 14: 522-05, 1990.

15. DAVIES.J.M. Antipsychotic drugs. In: Kaplan, H.S. \& Sadock, B.J. Comprehensive textbook of psychiatry. 4 rd. ed. Baltimore, Williams \& Wilkins, 1985. v. 2 p. 1481-513.

16. DE JONG. A.; GIEL, R.; SLOOFF, C.J.: WIERSMA, D. Social disability and outcome in schizophrenic patient s. $\mathrm{Br}$. J. Psychiatry, 147: 631-6, 1985.

17. DEAN, A.G.; DEAN, J.A.; BURTON, A.H.; DICKER, R.C. Epi Info, version 5.01: a word processing, database, and statistics program for epidemiology on microcomputers. Georgia, USD, Inc., 1990.

18. FRIERS, T. The future of psychiatric case registers. In: Cooper, B. Psychiatric epidemiology. London, Croom Helm, 1987. p. 335-51.

19. GOLDBERG, D. Cost-effectivesness studies in the treatment of schizophrenia: a review. Schizopr.Bult., 17:453-9, 1991.

20. HAFNER, H. \& AN DER HEIDEN, W. The evaluation of mental health care systems. Br. J. Psychiatry, 155:12-7. 1989.

21. HARDING, C,M.; ZUBIN, J,: STRAUSS, J.S. Chronicity in schizophrenia: revesited. BrJ. Psychiatry Suppl. 161:2737, 1992.

22. IACOPONI, E.: LARANJEIRAS, R.R.; MARI, J.J. Brazil: a giant wakes up to progress and inequality. In: Appleby, L. \&Araya, R. Mental health services in the global village. London, Gaskell, 1991. p. 131-48,

23. ISAACS, A.D. \& BEBBINGTON, P. Strategies for the management of severe psychiatric illness in the community. Int. Rev. Psychiatry, 3: 71-82, 1991.

24. JABLENSKY, A.Epidemiology of schizophrenia. In:Bebbington, P. \& McGuffin. P. Schizophrenia: the major issues. Oxford, Heinemann Professional Publishing. 1988. p. 19-35.

25. JABLENSKY, A.; SCHWARTZ, R.; TOMOV, T. WHO Collaborative Study on Impairments and Disabilities Associated with Schizophrenic Disorders; a preliminary communication: objectives and methods. Acta Psychiatr. Scand. Suppl, 62 (285), 1980.

26. JOHNSTONE, E.C.; OWENS, D.G.C.; GOLD, A.; CROW T.J.; MACMILLAN,J.F. Schizophrenic patients discharged from hospital: a follow-up study. In: Ker, A. \& Snaith, P. Contemporary issues in schizophrenia. London, Gaskell. 1986. p. 346-51.

27. KISSLING, W. Ideal and reality of neuroleptic relapse prevention. Br.J. Psychiatry Suppl. 161:133-9, 1992.

28. KRAMER, M. The rising pandemic of mental disorders and associated chronic disseases and disabilities. Acta Psychiatr. Scand. Suppl., 62 (285): 382-397, 1980.

29. KUIPERS, L. Needs of relatives of long-term psychiatric patients. In: Thomicroft, G.; Brewin, C.R.; Wing. J.K Measuring mental health needs. 1993.

30. LAMB, H.R. Deinstitutionalization at the crossroads. Hosp. Community Psychiatry, 39: 941-5. 1988.

31. MARI, J.J. Psychiatric care in Brasil. İn: Brown, S. Psychiatry in developing countries. London, Gaskell, 1983, p. $7-9$.

32. MARI. J.J. A epidemiologia da esquizofrenia.J. Bras Psiquiatr. 38: 180-3, 1989.

33. MENEZES, P.R. \& SCAZUFCA, M. Estudo de confiabilidade da versão em Português da "Escala de Avaliação da Incapacitação Psiquiátrica (WHO/DAS)". J. ABP-APAL. [in press].

34. MICHELS, R. The cost of schizophremia. London, Royal Society of Medicine, 1992.

35. SALIT, S.A. \& MARCOS, L.R. Have general hospitals become chronic care institutions for the mentally ill? Am. $J$ Psychyatry, 148:892-7, 1991

36. SANTANA, V.S.; ALMEIDA, N. F': MARI, J.J. Revisão dos estudos epidemiológicos en saúde mental no Brasil: $1^{\text {a }}$ parte. J. Bras. Psiquiatr., 37, 227-31, 1988.

37. SCHUBART, C.: KRUMM. B.; BIEHL. H.: SCHWARTZ, R. Measurement of social disability in a schizophrenic patient group. Soc. Psychiatry, 21: 1-9, 1986.

38. SHIRAKAWA, I. O ajustamento social na esquizofrenia. São Paulo, 1989. [PhD Thesis submitted to the Escola Paulista de Medicina].

39. TANSELLA, M. Community care without mental hospitais: ten-years experience. Psychol. Med. Monogr. Suppl., 19: 47-8, 1991. 
40. THORNICROFT, G. \& BEBBINGTON, P. Deinstitutionalization: from hospital closure to service development. Br.J. Psychiatry, 155:739-53, 1989.

41. WESTERMEYER, J.F. \& HAROW, M. Course and outcome in schizophrenia. In: Tsuang, M.T. \& Simpson, J.C. Handbook of schizophrenia: nosology, epidemiology and genetics. Amsterdam, Elsevier Science Publishers. B.V. 1988,v. 3. p. 205-44.

42. WILLIAMS, P. The problem of dignosis in psychiatric research. J.R. Soc. Med., 79: 1-2, 1986.

43. WILLIAMS,R,; WALSH,D.; DALBY,J.T.Services to schizophrenic patients: Epidemiological and cost-effectiveness issues. Ir.J.Psychol. Med., 9: 83-9, 1992.

44. WING, J.K.; COOPER, J.E.; SARTORIUS, N. Measurement

\section{Appendix 1.}

WHO Psychiatric Disability Assessment Schedule (WHOIDAS)*

\section{Section 1: Overall Behavior}

1.1 Patient's self-care

(i) personal hygiene

(ii) feeding habits

(iii) keeping living space tidy

1.2 Underactivity

time during the day spent in what culture considers to be doing nothing (e.g., lying awake in bed, sitting still and unoccupied, not talking to others)

\subsection{Slowness}

overall speed of movements and agility in carrying out daily activities

1.4 Social withdrawal

(a) active avoidance of interacting with people

(b) active avoidance of being in the physical presence of other people

\section{Section 2: Social Role Performance}

2.1 Participation in household activities

(i) participation in common activities of the household (e.g., having meals together, watching television, etc.)

(ii) participation in decision-making concerning the household (e.g., children, money, etc.)

* The Portuguese version may be obtained by contacting Dr Ana C. Chaves, Dep. de Psiquiatria e Psicologia Médica, Escola Paulista de Medicina, Rua Botucatu, 740, 3andar, 04023-900 - S. Paulo, SP - Brazil. and classification of psychiatric symptoms: a instruction manual for the PSE and Catego Program. London. Cambridge University Press, 1974.

45. WING, J.K. \& STURT, E. The PSE-ID-CATEGO System: a supplementary manual. London, Institute of Psychiatry, 1978. [mimeografado].

46. WORD HEALTH ORGANIZATION. Intemational classification of diseases. 9th version. Geneva, 1975.

47. WORD HEALTH ORGANIZATION. Psychiatric disability assessment schedule (WHO/DAS). Geneva, 1988.

Recebido para publicação em 12.3 .93 Aprovado para publicação em 13.7 .93

2.2 Marital role: affective relationship to spouse

(i) communication with spouse about ardinary events

(ii) ability to show affection and warmth towards spouse

(iii) spouse's feeling that patient is a source of support

2.3 Marital role: sexual relations with spouse

(i) occurrence of sexual intercourse

(ii) whether patient experiences sexual relations as satisfactory

(iii) whether spouse experiences sexual relations as satisfactory

2.4 Parental role: interest and care of child

(i) undertaking and performance of child care tasks appropriately

(ii) interest in child

2.5 Sexual role: relationships with persons other than marital partner (unmarried patient or patient not living with apouse)

(i) heterosexual (or homosexual) interests and emotional responsiveness

(ii) actual relationship or contacts soughtby patient

2.6 Social contacts: friction in interpersonal relationships outside the household, overt conflictive behavior on the part of the patient involving inappropriate arguments, annoyance, anger or marked initability arising in situations outside own home

2.7 Occupational role: work performance (including students and persons in sheltered employment)

(i) whether patient conforms to the work routine

(ii) quality of performance and output 
2.8 Occupational role: interest in getting a job or in going back to work or studies

(i) interest in obtaining or returning to a job or studies

(ii) actual steps undertaken to do so

2.9 Interests and information

(i) interest shown in local or world events

(ii) effort to obtain such information

2.10 Patient's behaviour in emergencies or in out-ofthe-ordinary situations that have occurred in the last six months

(i) sickness or accident affecting a family member

(ii) sickness or accident involving other people

(iii) minor emergencies

(iv) any other non-routine situation out of the routine for the patient, normally requiring action
All items in section 1 and 2 are rated:

$0=$ no dysfunction

$1=$ minimum dysfunction

$2=$ obvious dysfunction

$3=$ serious dysfunction

$4=$ very serious dysfunction

$5=$ maximum dysfunction

\section{Section 5: Global Evaluation}

In view of all the information recorded and rated in the schedule, what is the overall assessment of the patient's current social adjustment?

$0=$ excellent or very good adjustment

$1=$ good adjustment

$2=$ fair adjustment

$3=$ poor adjustment

$4=$ very poor adjustment

$5=$ severe maladjustment

$8=$ impossible to make a rating 